of $\mathrm{Ph}$.D. theses and prepared a section on the wood destroying Basidiomycetes for the Mycology Guidebook, R.B. Stevens (ed.), Seattle, 1974.

In spite of a persistent health problem for most of her life she had an indefatigable spirit. After retirement, the health problem was partially resolved and with renewed, more comfortable mobility she travelled widely, usually in search of decay fungi and ideas for research. For example, she spent a few months at the University of Florida, Gainesville, examining specimens of decay fungi. Later, she combined study in Pretoria, South Africa with a safari in Kruger National Park. Mildred had a splendid sense of humour and was interested in all that went on around her; she was an avid reader, a keen photographer and gardener and regularly attended chamber music and orchestral concerts.

When Mildred arrived in Ottawa in 1935 she attended Parkdale United Church where she taught a class of senior girls. Later she was a long time member of Woodroffe United Church. Mildred made friends easily and maintained these over the years. Newcomers to the Mycology Department were regularly made welcome in her home.

Mildred was a dedicated scientist with a keen innovative mind: her studies greatly benefited mycology and forest pathology. She was modest about her accomplishment, but her contributions to applied and theoretical mycology have been recognized widely not only by the very numerous citations of her groundbreaking publications but also in other ways. In 1963 she was elected a Fellow of the Royal Society of Canada. In 1968 she was an invited speaker at an International Symposium on "Evolution in the Higher Basidiomycetes," in Knoxville, Tennessee. The Canadian Phytopathological Society bestowed on her an Honorary Membership in 1969 after her long time service. She was awarded the George Lawson Medal for outstanding research by the Canadian Botanical Association in 1972, and in 1986 the Mycological Society of America presented her with the Distinguished Mycologist Award. Her notes, collection of reprints and books were presented to the National Mycological Herbarium (DAOM) by her family.

$$
\begin{aligned}
& \text { Dr. S.J. Hughes, F.R.S.C. } \\
& \text { From Proceedings of the } \\
& \text { Royal Society of Canada }
\end{aligned}
$$

\title{
Gold Medal Winners
}

\section{Brad Collins, University of British Columbia}

Brad Collins is a forest science major, with a concentration in ecology. In the 3 years Brad has been in the Faculty of Forestry, he has become involved in student government, intramural sports and has pursued academic excellence. He was elected as Faculty Student Liaison with the Forestry Undergraduate Society in 19961997, and then as R.P.F. Liaison this year. He has also been actively involved individually, and as a team captain, in forming forestry teams to compete in UBC intramural sports events such as the great trek fun run, storm the wall, day of the long boat and the triathlon/duathlon. His academic distinction has been rewarded with the ABCPF, Robert E. Mills, and John Splan academic scholarships. Brad hopes to pursue graduate studies and then become a consultant in forest ecology.

\section{Cathy Lefrançois, Cegep Chicoutimi}

Madame Lefrançois est une excellente étudiante, dont le dossier scolaire est de première qualité. Cette étudiante s'implique dans les activités étudiantes comme par exemple le bal des finissants de sa promotion. Elle s'intéresse beaucoup au secteur forestier de sa région en étant toujours alerte sur tout ce qui se passe dans ce secteur.

En plus de ces qualités, madame Lefrançois possède un caractère dynamique et elle est polie, assidue et attentionnée.

\section{CIF/IFC Continuing Forestry Education Certificates}

Congratulations to the following individuals for completing the requirements for the Continuing Forestry Education Certificate.

\section{John Barton, CFT (New Brunswick)}

Mr. Patrick Duffy, Ph.D., R.P.F. (British Columbia)

Ron Hallett, RPF (2nd time) (New Brunswick)

Girvan Harrison, RPF CFT (New Brunswick)

John Henderson, RPF (2nd time) (New Brunswick)

David MacLean (New Brunswick)

Todd MacPherson, CFT (New Brunswick)

Mr. Peter MacQuarrie (Nova Scotia)

Kim Mann, RPF CFT (New Brunswick)

Kenneth McGinn, CFT (New Brunswick)

Rod O'Connell, RPF (New Brunswick)

Dale Simpson (New Brunswick)

Ron Smith, RPF (2nd time) (New Brunswick)

Ed Swift, RPF (2nd time) (New Brunswick)

8 April 1998 